\title{
COST-EFFECTIVENESS OF ANASTROZOLE, IN COMPARISON WITH TAMOXIFEN, IN THE ADJUVANT TREATMENT OF EARLY BREAST CANCER IN BRAZIL
}

\author{
Marcelo Fonseca $^{1 *},{\text { Gabriela T B Araú } 0^{2} \text {, Everardo D. SaAd }}^{3}$ \\ Trabalho realizado na AxiaBio Consultoria Econômica, S.Paulo, SP
}

\author{
*Correspondência: \\ Rua Setembrino Woitechumas \\ $n^{\circ} .38$ - Casa 4 - Brooklin \\ São Paulo - SP \\ CEP: 04563-090 \\ Telefone: (11) 5539-4969 \\ marcelo.fonseca@axia.bio.br
}

\begin{abstract}
SUMMARY
ObJective. Breast cancer, a leading type of cancer in many developing countries, is the most frequent non-cutaneous tumor in Brazil. Hormone therapy is the standard of care in the adjuvant treatment of early-stage, hormone-receptor-positive disease, and both tamoxifen and third-generation aromatase inhibitors are options in postmenopausal women. The comparative cost-effectiveness of different treatment strategies is of considerable interest in societies facing limited resources.

METHODS. In an attempt to compare cost-effectiveness of upfront treatment with tamoxifen or anastrozole, the medical and economic results in a hypothetical cohort of 64-year-old postmenopausal women, was analyzed considering the Brazilian healthcare system in 2005, the primary perspective of the private sector, and a lifetime horizon. Data from the ATAC Trial, Markov modeling, a modified Delphi panel, and microcosting (in Brazilian $\mathrm{R} \$$ ) were used to estimate costs and effectiveness of the two upfront strategies.

Results. The model estimated a gain of 0.55 discounted life-years for patients receiving anastrozole, relative to those treated with tamoxifen. With an incremental cost of $R \$ 15,141.15$, the model estimated that the cost-effectiveness of anastrozole, in relation to tamoxifen, was $\mathrm{R} \$ 27,326.80$. Monte Carlo simulations showed that approximately $50 \%$ of the cases fell below the threshold of $\mathrm{R} \$ 29,229.00$ per life-year gained, which is recommended by the World Health Organization for Brazil.

Conclusion. It was concluded that upfront anastrozole is a cost-effective option compared with tamoxifen in the adjuvant treatment of postmenopausal women with hormone-receptor-positive early breast cancer.
\end{abstract}

KEY wORDS: Aromatase inhibitors. Anastrozole. Breast neoplasms. Cost-benefit analysis. Delphi technique. Markov chains. Tamoxifen.

\section{INTRODUCTION}

Breast cancer is the most frequent non-cutaneous tumor type in Brazil, where it accounts for approximately 50,000 new cases each year ${ }^{1}$. It is also a leading type of cancer in many other developing countries, and is considered a public health problem ${ }^{2}$. A recent report suggests that breast cancer incidence is decreasing in the USA ${ }^{3}$, but this is unlikely in developing countries, where adoption of a Western diet and increasing use of mammography favor the incidence or rate of detection of this disease ${ }^{4}$.

Breast tumors express hormone receptors in approximately $75 \%$ of the patients diagnosed after menopause ${ }^{5,6}$. These women represent approximately three quarters of the breast cancer patients upon diagnosis ${ }^{7}$. Hormone therapy is considered a standard of care in the adjuvant treatment of early-stage disease in such cases. For almost two decades, the antiestrogen tamoxifen has been considered the standard hormone therapy in adjuvant treatment of postmenopausal women with early breast cancer ${ }^{8}$. More recently, third-generation aromatase inhibitors, including anastrozole, exemestane and letrozole, have improved the disease-free survival rates, in comparison with a 5 year treatment with tamoxifen ${ }^{9}$.

The upfront use of anastrozole for 5 years was approved in the USA in 2002, based on results of the Anastrozole, Tamoxifen, Alone or in Combination (ATAC) trial ${ }^{10}$. In the ATAC trial, anastrozole yielded a statistically significant longer diseasefree survival compared with tamoxifen or the combination of both agents. In addition, anastrozole significantly reduced the incidence of contralateral breast cancer. At median follow-up of 68 months, the relative risk reduction of recurrence, of a

1. Mestrado - Gerente Médico e Operacional do Núcleo de Gestão de Pesquisa da Universidade Federal de São Paulo - UNIFESP, São Paulo, SP

2. Diretora administrativa Axia.Bio Consultoria Econômica, São Paulo, SP

3. Médico e diretor da Dendrix Ltda, São Paulo, SP 
new primary breast cancer or death from any cause produced by anastrozole, compared with tamoxifen, was $17 \%$ in patients with hormone-receptor-positive tumors; in this same group, the relative risk reduction of recurrence or of a new primary breast cancer was $26 \%{ }^{11}$.

Given the superiority of upfront treatment with an aromatase inhibitor, compared with tamoxifen ${ }^{10,12}$, cost-effectiveness of these two agents is of interest especially in societies with limited resources. In this study, we sought to determine cost-effectiveness of anastrozole, compared with tamoxifen, in the adjuvant treatment of postmenopausal women with early breast cancer in Brazil. In addition, measurements in terms of life-years gained with the use of anastrozole, were also carried out.

\section{Methods}

\section{Development of the model}

We used a hypothetical cohort of 64-year-old postmenopausal women undergoing definitive surgery for local treatment of early breast cancer. These hypothetical patients were assumed to be similar to those from the ATAC trial. The study setting is the Brazilian healthcare system in the year 2005, with the primary perspective of the private healthcare sector (insurance companies, healthcare plans, health maintenance organizations and healthcare cooperatives), and with the lifetime horizon considered. We obtained data from the medical literature, including the ATAC trial ${ }^{10,11}$, the official published prices for medications ${ }^{13}$, procedures $^{14}$, and hospital supplies ${ }^{15}$ in Brazil, and national population statistics ${ }^{16}$. Information on the local patterns of care for breast cancer, complications and costs were obtained using a modified Delphi panel, a method commonly used in pharmacoeconomic studies ${ }^{17}$.

A Markov model was developed reflecting the natural history of breast cancer after a potentially curative local surgery. Markov models are used to represent the possible transitions of patients from one discrete health state to another in one of a finite number of states. Such models are useful when risks are continuous over time, when the timing of events is important, and when events may occur more than once. The health states used in the model were (1) alive and well, (2) locoregional or (3) distant recurrence, (4) experience of adverse event due to adjuvant treatment; (5) need to change treatment after an adverse event, (6) death from breast cancer, and (7) death from other causes. The model was used to simulate two cohorts of patients starting adjuvant treatment, one receiving anastrozole ( $1 \mathrm{mg}$ per day for the planned 5 years), and the other receiving tamoxifen (20 $\mathrm{mg}$ per day for the planned 5 years). In order to compensate for the uncertainty of the model parameters, we performed ten thousand Monte Carlo interactions, with variations in all the parameters.

\section{Health States and Costs}

The model assumed that all patients will receive adjuvant treatment (anastrozole or tamoxifen), and that each year the patients will transit among the health states previously described. Patients began in the health state "alive and well". The model considered the possible transitions from this state to those involving recurrence and death from other causes, with contralateral breast cancer considered as locoregional recurrence. The
Table 1 - Costs associated with the health states used in the model

\begin{tabular}{lcc}
\hline \multirow{2}{*}{ Health state } & \multicolumn{2}{c}{ Costs (R\$) } \\
\cline { 2 - 3 } & Anastrozole & Tamoxifen \\
\hline Alive and well from years 1 to 5 & $1,255.87$ & $1,339.57$ \\
Alive and well 6 years onwards & 551.64 & 635.34 \\
Treatment suspension from years 1 to 5 & $1,255.87$ & $1,339.57$ \\
Treatment suspension 6 years onwards & 551.64 & 635.34 \\
Adverse event & $1,206.67$ & 966.3 \\
Locoregional disease & $6,935.03$ & $6,935.03$ \\
Metastasis & $14,639.04$ & $14,639.04$ \\
Death due to breast cancer & $6,131.40$ & $6,131.40$ \\
\hline
\end{tabular}

model assumed that after locoregional or distant recurrences, no patient would return to the "alive and well" state, given that some studies suggest that patient outcome is not affected by local salvage treatment ${ }^{18}$, and that only a minority of patients with local recurrence after mastectomy ${ }^{19}$ or conservative surgery ${ }^{20}$ have a prolonged survival. Patients who died during the simulation did not make further transitions.

Microcosting was used to evaluate use of resources and cost of distinct clinical states (Table 1). Costs were calculated in Brazilian Reais ( $R \$$, with $R \$ 1.00$ equaling approximately US\$ 0.40 ) using a discount rate of $3 \%$, and performing sensitivity analyses for the economic results varying discount rates from $1.5 \%$ to $5 \%$, given the inherent uncertainty of the clinical and economic data. Incremental cost-effectiveness ratios are reported for the lifetime horizon.

\section{Probabilities}

Probabilities of adverse events were those observed in the ATAC trial ${ }^{11}$. Probabilities of recurrence derived from the timeto-recurrence curve of the ATAC trial, with a $26 \%$ reduction in women with hormone-receptor-positive tumors using anastrozole, compared with tamoxifen ${ }^{11}$. The model attributed probabilities of locoregional and distant recurrences in each group using data from the ATAC trial, assuming a constant pattern along the simulation. Such probabilities were $34.16 \%$ and $65.83 \%$ for locoregional and distant recurrences, respectively, in the anastrozole group, and $40.11 \%$ and $59.89 \%$ for locoregional and distant recurrences, respectively, in the tamoxifen group ${ }^{10}$. Outcome was simulated in terms of recurrence after the original trial follow-up period, assuming that the benefit of adjuvant anastrozole would last for the entire life of the patient. To achieve such a goal, an exponential function adjusted to extrapolate the original curve, as shown in Figure 1, was used.

After recurrence, the probability of death was influenced by the initial disease-free interval| ${ }^{18,19,21,22}$. As early recurrence typically portends a worse prognosis, the annual probabilities of distant disease and death in the model were greater in the first five years, in comparison with subsequent years. For death from breast cancer, annual probabilities were 0.50 in the first year, 0.41 in the second, 0.32 in the third, fourth and fifth, and 0.22 from the sixth year onwards ${ }^{23}$. The annual probabilities of distant disease after local recurrence derived from the curve presented by Kamby and Sengelov ${ }^{24}$. Finally, the annual probability of death from other causes was obtained from Brazilian vital statistics of $2001^{16}$. 
Table 2 - Cost per life-year gained when anastrozole is compared with tamoxifen in the adjuvant treatment of early breast cancer in Brazil

\begin{tabular}{lccccc}
\hline Alternative & Life-time cost per patient & Incremental cost & Effectiveness & Incremental effectiveness & Incremental cost/effectiveness ratio \\
\hline Tamoxifen & $\mathrm{R} \$ 32,424.30$ & & 14.39 & & \\
Anastrozole & $\mathrm{R} \$ 47,565.45$ & $\mathrm{R} \$ 15,141.15$ & 14.94 & 0.55 & $\mathrm{R} \$ 27,326.80$ \\
\hline
\end{tabular}

\section{RESULTS}

\section{Effectiveness}

Considering a lifetime horizon, the adjuvant treatment with tamoxifen resulted in 14.39 discounted life-years gained. With use of anastrozole, there was an additional gain of 0.55 discounted life-years, resulting in 14.94 discounted life-years gained. The discount rate used for the consequences was $1.5 \%$.

\section{Costs}

The mean lifetime cost, discounted at $3 \%$, was $R \$ 47,565.45$ for a patient receiving anastrozole, and $\mathrm{R} \$ 32,424.30$ for one receiving tamoxifen. For patients receiving anastrozole, approximately $49 \%$ of the cost was due to the drug itself. On the other hand, for patients receiving tamoxifen, nearly $46 \%$ of the expenses were for treatment of recurrences. The model predicts that such patients expend $17 \%$ more in recurrence treatment, when compared to patients receiving anastrozole. However, patients receiving anastrozole are predicted to expend, on the average, $15 \%$ more resources with post-treatment disease remission, in comparison with those receiving tamoxifen.

Costs related to the health states "locoregional recurrence", "distant recurrence" and "death" are higher in the group of patients treated with tamoxifen, whereas the cost during the "alive and well" state is higher for anastrozole.

\section{Cost-effectiveness}

During simulation involving the lifetime horizon, considering the gain of 0.55 discounted life-years for patients receiving anastrozole in relation to those receiving tamoxifen, and with an incremental cost of $\mathrm{R} \$ 15,141.15$, the model estimated that cost-effectiveness of anastrozole, in relation to tamoxifen, was $\mathrm{R} \$ 27,326.80$ (Table 2). Several univariate sensitivity analyses were performed (data not shown). The model was sensitive to the cost of adjuvant therapy and to probability of interrupting adjuvant treatment with anastrozole. Regarding tamoxifen, the model was sensitive to the cost of metastatic disease, probability of metastasis and probability of interrupting adjuvant treatment with tamoxifen. Figure 2 depicts findings of ten thousand Monte Carlo simulations for cost-effectiveness results. The line shows the threshold of $\mathrm{R} \$ 29,229.00$ per life-year gained, with approximately $50 \%$ of the simulations being below this threshold.

\section{Discussion}

Performance of a decision analytical model considering the Brazilian setting is indeed necessary because healthcare decision makers, mainly budget holders, must make decisions regarding reimbursement and inclusion of given drugs or interventions in therapeutic settings. A decision analytical model considering the Brazilian scenario is also needed because transferability of
Figure 1 - Time to disease recurrence projected on the bases of the original study data

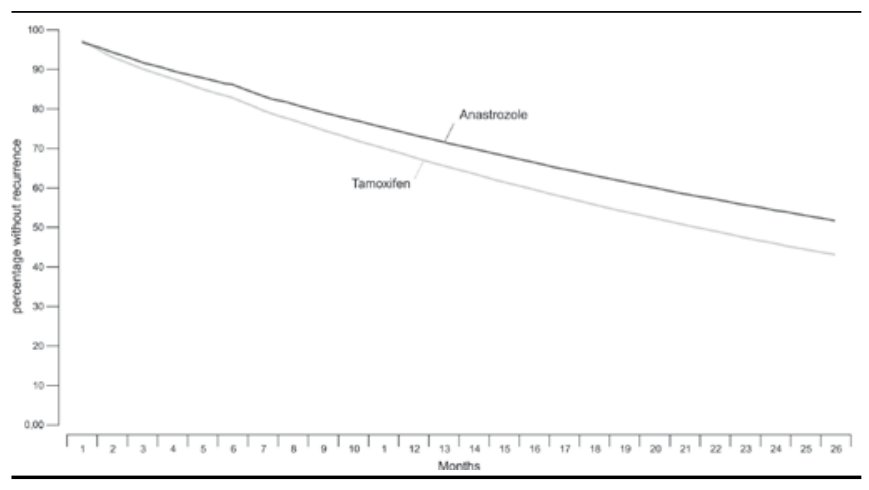

Figure 2 - Results of ten thousand Monte Carlo simulations for the cost-effectiveness

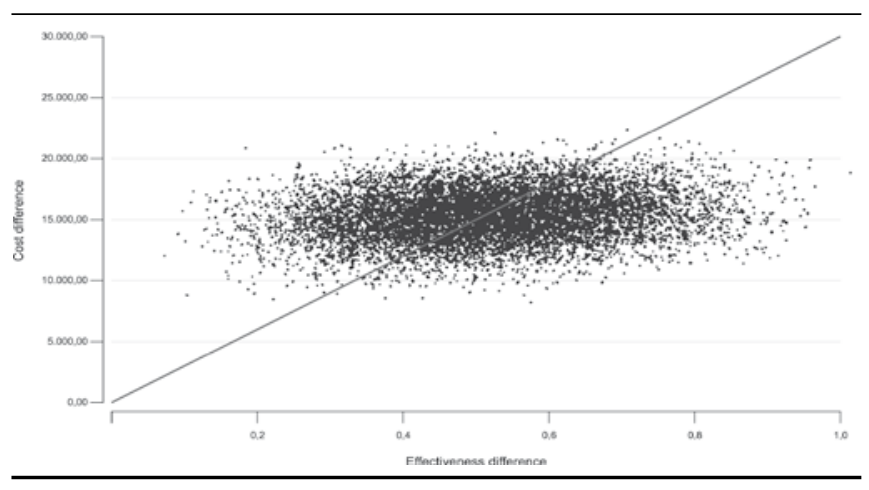

cost-effectiveness results from other countries is still a matter of research, can be potentially misleading and result in inefficient use of the scarce healthcare resources. Clinical data, on the other hand, are likely to be, for the most part, consistent between populations of different countries, and therefore clinical results can largely be extrapolated across national borders ${ }^{25}$. In fact, in this model it was assumed that Brazilian women with early breast cancer are similar to those studied in the ATAC trial. Once again, current evidence suggests that treatment effect and relative risk reduction may be more generalizable than prices, clinical practice patterns and resource use ${ }^{26}$. As a matter of fact, approaches that have been used for transferability advise that, at a minimum, there is a need for country-specific substitution of practice pattern data as well as unit cost data ${ }^{26}$. In order to identify the Brazilian clinical practice patterns and resource usage a modified Delphi 
panel was performed with Brazilian specialists, and results were used in the microcosting process.

In view of the latest ATAC results ${ }^{27}$, it can be stated that up to the $108^{\text {th }}$ month this model was able to adequately predict the pattern of disease free survival in this simulated population. This can be observed comparing the absolute percentual difference between tamoxifen and anastrozole patients who have recurrent disease at the $108^{\text {th }}$ month in the ATAC trial and in this model: $4.1 \% 27$ and $4.0 \%$, respectively. Further, the uncertainty surrounding clinical and economic data was assessed in this study by means of probabilistic sensitivity analysis (Monte Carlo simulation).

In many developed countries, acceptable cost-effectiveness thresholds have been defined for planning healthcare policies. However, no such definition is available in Brazil, a developing country facing limited healthcare resources. The World Health Organization (WHO) has suggested an acceptable costeffectiveness threshold as one that is less than three times the per-capita gross domestic product (GDP) ${ }^{28}$. In Brazil, where the yearly per-capita GDP is currently $R \$ 9,743.00^{29}$, an intervention with a cost-effectiveness of up to $\mathrm{R} \$ 29,229.00$ may therefore be considered as cost-effective by WHO standards. This model estimated that the lifetime cost-effectiveness of adjuvant treatment with anastrozole, in comparison with tamoxifen, is $\mathrm{R} \$$ $27,326.80$, when considering a 64-year-old postmenopausal patient with hormone-receptor-positive, early breast cancer.

Several other cost-effectiveness models for the comparison between adjuvant treatment with anastrozole or tamoxifen have been published. Hillner conducted a computer simulation model assessing the outcomes of 64-year-old women with estrogenreceptor-positive breast cancer treated with adjuvant anastrozole or tamoxifen for 5 years, using data from the ATAC trial ${ }^{30}$. His model predicted that adjuvant anastrozole would result in improvements in disease-free survival of 2.9 and 5.3 months after 12 and 20 years, respectively. In terms of overall survival, such improvements would be 0.9 months and 2.0 months, respectively, resulting in incremental cost-effectiveness lower than $\mathrm{R} \$ 100,000$ per life-year after 12 years. In addition, inclusion of quality-of-life weightings for nonfatal outcomes modestly favored anastrozole in the short term; in the long term, however, an increased risk of hip fracture from the use of anastrozole would curtail such benefit. They concluded that, from the societal perspective, the average woman will experience an overall lifetime benefit from the adjuvant use of anastrozole, with the incremental cost of this benefit near the upper limit of the range of incremental costs arbitrarily accepted in North America ${ }^{31}$. A second analysis conducted in the United States, on behalf of the ATAC Trialists' Group, concluded that upfront anastrozole is a cost-effective alternative to tamoxifen for the adjuvant treatment of postmenopausal women with estrogen-receptor-positive, early breast cancer ${ }^{32}$.

Rochhi and Verma conducted an economic analysis comparing anastrozole and tamoxifen in the adjuvant treatment of hormone-receptor-positive, postmenopausal patients with early breast cancer, using the typical patient from the ATAC trial over a lifetime horizon and the Canadian public healthcare perspective $^{33}$. In that study, resource utilization was drawn from Statistics Canada, supplemented by an expert panel. According to their model, patients treated with anastrozole incurred additional treatment costs, compared with patients receiving tamoxifen, but these costs were partially offset by reduced recurrences of breast cancer. Patients treated with anastrozole were projected to experience absolute reductions of $5.6 \%$ in the risk of first breast cancer recurrence and $2.8 \%$ in the risk of death from breast cancer. This corresponded to 30,000.00 Canadian dollars per life-year gained and 28,000.00 Canadian dollars per quality-adjusted life-year gained. The authors concluded that anastrozole therapy is effective and cost-effective as initial adjuvant therapy in this patient population, when compared to tamoxifen.

Other studies have assessed the economic impact of adjuvant treatment with anastrozole, when compared with tamoxifen, in different healthcare scenarios. Anastrozole was considered costeffective in the long term in Slovenia ${ }^{34}$ and Belgium ${ }^{35}$ taking into account the healthcare provider and healthcare system perspectives, respectively. In addition, a second study from Canada using the direct payer perspective concluded that upfront treatment with anastrozole is a cost-effective alternative to 5 years of tamoxifen ${ }^{36}$. Also, based upon ATAC results, and from the perspective of the United Kingdom National Health Service, Mansel et al. have recently shown that the estimated incremental cost-effectiveness of anastrozol compared with tamoxifen was $£ 17,656$ per QALY gained. This considered clinical settings similar to the above mentioned studies, with a greater than $90 \%$ probability that cost-effectiveness of anastrozole was below $£ 30,000$ per QALY gained (the UK threshold). The results of that study were robust for all parameters tested in sensitivity analysis ${ }^{37}$.

The cost-effectiveness of cancer treatment clearly varies across the globally diverse epidemiological and economic spectrum $^{38}$. Despite the fact that novel therapies are typically more expensive than existing alternatives, their prices tend to decrease along the years. In addition, availability of generic medications may further decrease treatment costs. Models such as the one used in this study are quite sensitive to increases in the price of medications ${ }^{30}$. As a corollary to this, decreases in the price ratio between anastrozole and tamoxifen will likely decrease the incremental cost-effectiveness of anastrozole. Also, the costeffectiveness of any cancer treatment will vary according to patient life expectancy. In Brazil, the life expectancy of women aged 64 is currently 19.3 years $^{39}$.

\section{CONCLUSION}

Given the clinical superiority of anastrozole over tamoxifen ${ }^{10,11,27}$, and the acceptable incremental cost-effectiveness of this strategy - shown in several studies ${ }^{30,} 32-35$ and confirmed in this one -, our analysis suggests that upfront treatment with anastrozole for 5 years may be the preferred adjuvant strategy for postmenopausal Brazilian women with hormone-receptorpositive, early breast cancer.

\section{Financial SUPPORT:}

AstraZeneca do Brasil

\section{Conflict of interest: none}




\section{Resumo}

\section{Custo-efETIVIDADE DO ANASTROZOL EM COMPARAÇÃo COM TAMOXIFENO NO TRATAMENTO ADJUVANTE DO CÂNCER DE MAMA PRECOCE NO BRASIL}

OBJETIVO. O câncer de mama, o mais comum em vários países desenvolvidos, é o tumor não cutâneo mais frequente no Brasil. A terapia hormonal é o tratamento adjuvante padrão para os estágios precoces, em doença com receptor hormonal positivo, e o tamoxifeno e os inibidores da aromatase de terceira geração são opções para mulheres na pós-menopausa. A comparação do custo-efetividade dos diferentes tratamentos é de grande interesse nas sociedades com limitações de recursos.

Métodos. Para comparar a custo-efetividade dos tratamentos com tamoxifeno ou anastrozol, foram analisados os resultados médicos e econômicos em uma coorte hipotética de mulheres com 64 anos de idade, considerando o sistema de saúde Brasileiro em 2005, sob a perspectiva do setor privado e o horizonte de tempo de uma vida. Usamos dados do Estudo ATAC, um modelo de Markov, um painel de Delphi modificado, e microcosting (em reais $R \$$ ) para estimar os custos e a efetividade das duas estratégias.

Resultados. O modelo estimou um ganho de 0.55 anos de vida descontados para pacientes recebendo anastrozol em relação àquelas tratadas com tamoxifeno. Com um custo marginal de $R \$ 15.141,15$, o modelo estimou que o custoefetividade do anastrozol em relação ao tamoxifeno era de $R \$$ 27.326,80. As simulações de Monte Carlo mostraram que aproximadamente $50 \%$ dos casos estavam abaixo do limite de $R \$ 29.229,00$ por ano-vida ganho, que é o recomendado pela Organização Mundial da Saúde para o Brasil.

Conclusão. Nós concluímos que o anastrozol é uma opção custo-efetivo comparado ao tamoxifeno no tratamento adjuvante de câncer de mama precoce em mulheres na pós-menopausa com receptor de hormônio positivo. [Rev Assoc Med Bras 2009; 55(4): 410-5]

UnITERmos: Inibidores da aromatase. Anastrozol. Neoplasias da mama. Avaliação de custo-efetividade. Técnica Delfos. Cadeias de Markov. Tamoxifeno.

\section{REFERENCES}

1. Brasil. Ministério da Saúde. Instituto Nacional de Câncer. Estimativa 2006 Incidência de câncer no Brasil. Rio de Janeiro: INCA; 2005.

2. Veronesi U, Boyle P, Goldhirsch A, Orecchia R, Viale G. Breast cancer. Lancet. 2005;365:1727-41

3. Ravdin PM, Cronin KA, Howlader N, Berg CD, Chlebowski RT, Feuer EJ, et al. The decrease in breast-cancer incidence in 2003 in the United States. N Engl J Med. 2007;356:1670-4.

4. Leung GM, Thach TQ, Chan E, Foo W, Meng O, Fielding R, et al. Short-term, medium-term, long-term, and lifetime risks of developing and dying of breast carcinoma in a Westernized Chinese population: Evidence from Hong Kong between 1976 and 2000. Cancer. 2005;103:501-8.

5. Elwood JM, Godolphin W. Oestrogen receptors in breast tumours: associations with age, menopausal status and epidemiological and clinical features in 735 patients. Br J Cancer. 1980;42:635-44.

6. Nadji M, Gomez-Fernandez C, Ganjei-Azar P, Morales AR. Immunohistochemistry of estrogen and progesterone receptors reconsidered: experience with 5,993 breast cancers. Am J Clin Pathol. 2005;123:21-27.

7. Hankey BF, Miller B, Curtis R, Kosary C. Trends in breast cancer in younger women in contrast to older women. J Natl Cancer Inst Monogr. 1994:7-14.

8. Effects of adjuvant tamoxifen and of cytotoxic therapy on mortality in early breast cancer. An overview of 61 randomized trials among 28,896 women. Early Breast Cancer Trialists Collaborative Group. N Engl J Med. 1988;319:1681-92.
9. Colozza M, de Azambuja E, Personeni N, Lebrun F, Piccart MJ, Cardoso F. Breast cancer: achievements in adjuvant systemic therapies in the pre-genomic era. Oncologist. 2006;11:111-25.

10. Baum M, Budzar AU, Cuzick J, Forbes J, Houghton JH, Klijn JG, et al. Anastrozole alone or in combination with tamoxifen versus tamoxifen alone for adjuvant treatment of postmenopausal women with early breast cancer: first results of the ATAC randomised trial. Lancet. 2002;359:2131-9.

11. Howell A, Cuzick J, Baum M, Buzdar A, Dowsett M, Forbes JF, et al. Results of the ATAC (Arimidex, Tamoxifen, Alone or in Combination) trial after completion of 5 years adjuvant treatment for breast cancer. Lancet. 2005;365:60-2.

12. Thürlimann B, Keshaviah A, Coates AS, Mouridsen H, Mauriac L, Forbes JF, et al. A comparison of letrozole and tamoxifen in postmenopausal women with early breast cancer. N Engl J Med. 2005;353:2747-57.

13. Revistakairos.com [Internet site]. [citado 25 set 2005]. São Paulo: Kairos; 2005. Disponível em: http://www.revistakairos.com/revista/bra/default bra.asp.

14. Calcmed Tabelas: tabelas convênios [computer software]. Version 1.17. São Paul: Visual Line Design; 2001.

15. Revista Simpro Hospitalar. 2005;7(38)

16. Brasil. Ministério da Saúde. Rede Interagencial de Informações para a Saúde. [citado 20 abr 2006]. Disponível em: http://tabnet.datasus.gov.br/ cgi/deftohtm.exe?idb2003/a08.def.

17. Evans $C$. The use of consensus methods and expert panels in pharmacoeconomic studies: practical applications and methodological shortcomings. In: Mallarkey G. Economic Evaluation in Healthcare. Hong Kong: Adis International, 1999. p.103.

18. Le MG, Arriagada R, Spielmann M, Guinebretière JM, Rochard F. Prognostic factors for death after an isolated local recurrence in patients with early-stage breast carcinoma. Cancer. 2002;94:2813-20.

19. Willner J, Kiricuta IC, Kolbl O. Locoregional recurrence of breast cancer following mastectomy: always a fatal event? Results of univariate and multivariate analysis. Int J Radiat Oncol Biol Phys. 1997;37:853-63.

20. Komoike Y, Akiyama F, lino Y, Ikeda T, Akashi-Tanaka S, Ohsumi S, et al. Ipsilateral breast tumor recurrence (IBTR) after breast-conserving treatment for early breast cancer: risk factors and impact on distant metastases. Cancer. 2006;106:35-41.

21. Schmoor C, Sauerbrei W, Bastert G, Schumacher M. Role of isolated locoregional recurrence of breast cancer: results of four prospective studies. J Clin Oncol. 2000;18:1696-708.

22. Doyle T, Schultz DJ, Peters C, Harris E, Solin LJ. Long-term results of local recurrence after breast conservation treatment for invasive breast cancer. Int J Radiat Oncol Biol Phys. 2001;51:74-80.

23. Lee JH, Glick HA, Hayman JA, Solin LJ. Decision-analytic model and costeffectiveness evaluation of postmastectomy radiation therapy in high-risk premenopausal breast cancer patients. J Clin Oncol. 2002;20:2713-25.

24. Kamby C, Sengelov L. Pattern of dissemination and survival following isolated locoregional recurrence of breast cancer. A prospective study with more than 10 years of follow up. Breast Cancer Res Treat. 1997;45:181-92.

25. Haycox A et Bagust A. Pharmacoeconomics and clinical trials. In Walley $T$, Haycox A, Boland A. Pharmacoeconomics.Spain: Elsevier Science Limited; 2004. p.127-40

26. International Society for Pharmacoeconomics and Outcomes Research. Task Forces - Transferability of economic evaluations across jurisdictions: ISPOR good research practices task force report [text in Internet]. Lawrenceville: ISPOR; 2008 [cited in 2008 oct 8] Available at: http://www. ispor.org/councils/ documents/MSEconTransTFFinalReport.pdf

27. Arimidex, Tamoxifen, Alone or in Combination (ATAC) Trialists Group, Forbes JF, Cuzick J, Buzdar A, Howell A, Tobias JS, Baum M. Effect of anastrozole and tamoxifen as adjuvant treatment for early-stage breast cancer: 100-month analysis of the ATAC trial. Lancet Oncol. 2008;9:45-53.

28. World Health Organization. WHO commission on macroeconomics and health: investing in health for economic development. Report of the commission on macroeconomics and health. Geneva: World health Organization; 2001

29. Brasil. Instituto Brasileiro de Geografia e Estatística (IBGE). Contas nacionais trimestrais - Indicadores de volume e valores correntes. [citado $27 \mathrm{abr}$ 2006]. Disponível em: http://www.ibge.gov.br/home/presidencia/noticias/ noticia_visualiza.php?id_noticia $=337 \& i d \_p a g i n a=1$.

30. Hillner BE. Benefit and projected cost-effectiveness of anastrozole versus tamoxifen as initial adjuvant therapy for patients with early-stage estrogen receptor-positive breast cancer. Cancer. 2004;101:1311-22.

31. Laupacis A, Feeny D, Detsky AS, Tugwell PX. How attractive does a new technology have to be to warrant adoption and utilization? Tentative guidelines for using clinical and economic evaluations. CMAJ. 1992;146:473-81.

32. Locker GY, Mansel R, Cella D, Dobrez D, Sorensen S, Gandhi SK, et al. Costeffectiveness analysis of anastrozole versus tamoxifen as primary adjuvant therapy for postmenopausal women with early breast cancer: a US healthcare system perspective. The 5-year completed treatment analysis of the ATAC (Arimidex, Tamoxifen Alone or in Combination) trial. Breast Cancer Res Treat. 2007;106(2):229-38. 
COST-EFfectiveness of ANASTROZOLE, IN COMPARISON WITH TAMOXIFEN, IN THE ADJUVANT TREATMENT OF EARLY BREAST CANCER IN BRAZIL

33. Rocchi A, Verma S. Anastrozole is cost-effective vs tamoxifen as initial adjuvant therapy in early breast cancer: Canadian perspectives on the ATAC completedtreatment analysis. Support Care Cancer. 2006;14:917-27.

34. Piskur P, Sonc M, Cufer T, Borstnar S, Mrhar A. Pharmacoeconomic aspects of adjuvant anastrozole or tamoxifen in breast cancer: a Slovenian perspective. Anticancer Drugs. 2006;17:719-24.

35. Moeremans K, Annemans L. Cost-effectiveness of anastrozole compared to tamoxifen in hormone receptor-positive early breast cancer. Analysis based on the ATAC trial. Int J Gynecol Cancer. 2006;16(Suppl 2):576-8.

36. Skedgel C, Rayson D, Dewar R, Younis T. Cost-utility of adjuvant hormone therapies for breast cancer in post-menopausal women: sequential tamoxifen-exemestane and upfront anastrozole. Breast Cancer Res Treat. 2007;101:325-33

37. Mansel R, Locker G, Fallowfield L, Benedict A, Jones D. Cost-effectiveness analysis of anastrozole vs tamoxifen in adjuvant therapy for early stage breast cancer in the United Kingdom: the 5-year completed treatment analysis of the ATAC (Arimidex, Tamoxifen alone or in combination) trial. Br J Cancer. 2007;97:152-61.

38. Sikora K, Advani S, Koroltchouk V, Magrath I, Levy L, Pinedo H, et al. Essential drugs for cancer therapy: a World Health Organization consultation. Ann Oncol. 1999; 10:385-390.

39. Brasil. Instituto Brasileiro de Geografia e Estatística (IBGE).Tábuas completas de mortalidade. [citado 14 maio 2007]. Disponível em: http://www.ibge.gov. br/home/estatistica/populacao/tabuadevida/2005/defaulttab.shtm.

Artigo recebido: 04/04/08

Aceito para publicação: 16/02/09 